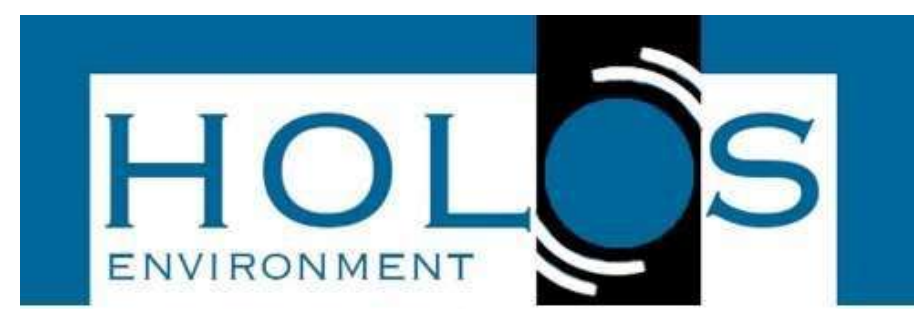

\title{
EFFICIENCY OF THE ELECTROCHEMICAL TREATMENT OF TEXTILE EFFLUENT USING TWO CONFIGURATIONS OF SACRIFICIAL ELECTRODES
}

\section{EFICIÊNCIA DO TRATAMENTO ELETROQUÍMICO DE EFLUENTE TÊXTIL UTILIZANDO DUAS CONFIGURAÇÕES DE ELETRODOS DE SACRIFÍCIO}

\author{
Leandro Fleck¹, Jeysa Piza Santana Passos², Andrieli Cristina Helmann², Eduardo Eyng ${ }^{3}$, \\ Laercio Mantovani Frare ${ }^{3}$, Fábio Orssatto ${ }^{3}$
}

Artigo recebido em: 22/02/2016 e aceito para publicação em: 04/01/2018.

DOI: http://dx.doi.org/10.14295/holos.v18i1.12155

\begin{abstract}
Textile industries have as main characteristic the generation of effluents with high color, and efficient treatment techniques are necessary. In this context, this study compared the efficiency of the electrochemical treatment for color removal from synthetic textile effluent using two configurations of sacrificial electrodes, parallel plates and array of cylindrical electrodes. For application of the electroflocculation technique, an electrochemical reactor was used, in a laboratory scale, operated in a continuous flow. The synthetic textile effluent was prepared with preset concentrations of reactive dye Blue $5 G$ and sodium chloride. Sacrificial iron (Fe) electrodes with different configurations were used: parallel plates and cylindrical electrodes. The Hydraulic Retention Time (HRT) and electric current density (j) were controlled, and their effects on color removal were evaluated using a Central Composite Rotational Design (CCRD) composed of 12 trials. For the electrochemical treatment using parallel plates, the color removal efficiency ranged from $56.13 \%$ to $98.95 \%$ and for the electrochemical treatment using an array of cylindrical electrode, the color removal efficiency varied from $2.11 \%$ to $97.84 \%$. The mathematical models representative of the process explained a high proportion of the total data variability, with a coefficient of variation of $99.49 \%$ and $97.21 \%$ for parallel plates and arrangement of cylindrical electrodes, respectively. The electrochemical treatment using parallel plates presents advantages over the configuration using a cylindrical electrode array, since the color removal efficiency is superior under the same operating conditions, representing economic and environmental gains.
\end{abstract}

Keywords: Dyes. Cylindrical electrodes. Electroflocculation. Mathematical modeling. Parallel plates.

Resumo: Indústrias têxteis possuem como principal característica a geração de efluentes com elevada coloração, sendo necessárias técnicas eficientes de tratamento. Neste contexto, o presente artigo tem como objetivo comparar a eficiência do tratamento eletroquímico para a remoção de cor de efluente têxtil sintético utilizando duas configurações de eletrodos de sacrifício, placas paralelas e arranjo de eletrodos cilíndricos. Para a aplicação da técnica de eletrofloculação, utilizou-se um reator eletroquímico, em escala laboratorial, operado em fluxo contínuo. O efluente têxtil sintético foi preparado com concentrações preestabelecidas de corante reativo azul $5 \mathrm{G}$ e cloreto de sódio. Utilizou-se eletrodos de sacrifício de ferro ( $\mathrm{Fe}$ ) com diferentes configurações: placas paralelas e eletrodos cilíndricos. Foram controlados os fatores Tempo de Retenção Hidráulica (TRH) e densidade de corrente elétrica (j), sendo seus efeitos sobre a remoção de cor avaliados utilizando-se um delineamento composto central rotacional (DCCR) composto por 12 ensaios. Para o tratamento eletroquímico utilizando placas paralelas a eficiência de remoção da cor variou de $56,13 \%$ a $98,95 \%$ e para o tratamento eletroquímico utilizando arranjo de eletrodos cilíndricos, a eficiência de remoção da cor variou de $2,11 \%$ a $97,84 \%$. Os modelos matemáticos representativos do processo explicam elevada parcela da variabilidade total dos dados, apresentando coeficiente de variação de $99,49 \%$ e 97,21\%, para

\footnotetext{
1 Universidade Estadual do Oeste do Paraná. E-mails: fleckmissal@gmail.com)

2 Engenharia Ambiental, Universidade Tecnológica Federal do Paraná. E-mails: (jeysa passos@hotmail.com, andrieli.utfpr@hotmail.com)

3 Programa de Pós-graduação em Tecnologias ambientais (PPGTAMB) - Universidade Tecnológica Federal do Paraná. Emails: (eduardoeyng@utfpr.edu.br, laercio@utfpr.edu.br, orssatto@utfpr.edu.br)
} 
placas paralelas e arranjo de eletrodos cilíndricos, respectivamente. O tratamento eletroquímico utilizando placas paralelas apresenta vantagens frente a configuração utilizando arranjo de eletrodos cilíndricos, uma vez que, a eficiência de remoção de cor é superior sob as mesmas condições operacionais, representando ganhos econômicos e ambientais.

Palavras-chave: Corantes. Eletrodos cilíndricos. Eletrofloculação. Modelagem matemática. Placas paralelas.

\section{INTRODUCTION}

Textile industries are complex and formed by fragmented and heterogeneous sectors, composed of small and medium companies (HASANBEIGI et al., 2012). In agreement with Paschoal and Tremiliosi-Filho (2005), a strong staining is the predominant characteristic in the textile effluent, which is due to the different dyes used in the fabric dyeing stage, and according to Carneiro et al., (2010), the azo chromophore group is the most used, corresponding to $65-70 \%$ of all the reactive dyes produced.

Physical processes associated with chemical processes have been used to remove dyes from textile effluents, including chemical coagulation, ozonation, ion exchange, activated carbon, membrane filtration, adsorption, and electrochemical treatments such as electroflocculation (ROBINSON et al., 2001; AKSU and TEZER, 2005).

Electroflocculation is one of the most efficient techniques for removal of intensive color and organic compounds in liquid effluents, besides reducing the generation of sludge (DANESHVAR et al., 2006). This technique occurs in a chemical reactor, where the oxidation is carried out by means of metal electrodes immersed in the effluent, where a certain potential difference is applied. It is considered a simple, reliable and low cost process for the treatment of effluents, not requiring the addition of chemical products (CIARDELLI and RANIERI, 2001; DANESHVAR et al., 2006; CERQUEIRA et al., 2009).

According to Aquino Neto et al., (2011), the electroflocculation involves three successive steps: 1) in situ generation of the coagulant due to electrolytic oxidation of the sacrificial electrode (metallic anode); 2) destabilization of contaminants and 3) flotation of coagulated materials due to the formation of microbubbles from the electrolysis of the water. Electrochemical reactions that occur with the metal $(\mathrm{Fe})$ and the electrolysis are presented in Equations 1 to 4 (CERQUEIRA et al., 2009): 
In the anode:

$$
\begin{gathered}
\mathrm{Fe}_{(s)} \rightarrow \mathrm{Fe}^{2+}(a q)+2 e^{-} \\
\mathrm{Fe}^{2+}{ }_{(a q)}+2 \mathrm{OH}_{(a q)}^{-} \rightarrow \mathrm{Fe}(\mathrm{OH})_{2(s)}
\end{gathered}
$$

In the cathode:

$$
2 \mathrm{H}_{2} \mathrm{O}_{l}+2 e^{-} \rightarrow \mathrm{H}_{2(g)}+2 \mathrm{OH}_{(a q)}^{-}
$$

Global reaction:

$$
\mathrm{Fe}_{(s)}+2 \mathrm{H}_{2} \mathrm{O}_{l} \rightarrow \mathrm{Fe}(\mathrm{OH})_{2(s)}+\mathrm{H}_{2(g)}
$$

Electroflocculation represents an alternative to conventional coagulation/flocculation methods, because unlike these, the coagulants (iron and aluminum) are added to the suspension by dissolution of the anode in the electrochemical reactor. Thus, these coagulating ions lead to the aggregation of the particles in water to be removed in a subsequent sedimentation or filtration process (SASSON and ADIN, 2010).

In this context, this study compared the efficiency of the electrochemical treatment for color removal of synthetic textile effluent using two configurations of sacrificial electrodes, parallel plates and array of cylindrical electrodes, under different conditions of hydraulic retention time and electric current density.

\section{MATERIAL AND METHODS}

\subsection{Electrochemical reactor}

For the application of electroflocculation, an electrochemical reactor was used, in a laboratory scale, operated in a continuous flow. The electrolytic cell was made with tempered glass with dimensions of $62 \mathrm{~cm}$ in length, $14 \mathrm{~cm}$ in width and $19 \mathrm{~cm}$ in height, with a useful volume of $9.038 \mathrm{~L}$.

Coupled to the reactor, there were an inlet reservoir and a reservoir for storing the treated synthetic textile effluent. A submerged pump was used to aid in reactor feed and in 
order to retain the sludge generated during the electrochemical treatment, baffles were used at the inlet and outlet of the system.

\subsection{Preparation of the synthetic textile effluent with reactive dye Blue $5 \mathrm{G}$}

For the electrochemical treatment with parallel plates, the synthetic textile effluent was prepared using water from the supply network with $50 \mathrm{mg} \mathrm{L}^{-1}$ reactive dye Blue $5 \mathrm{G}$ and $2 \mathrm{~g} \mathrm{~L}^{-1}$ Sodium Chloride ( $\left.\mathrm{NaCl}\right)$.

For the electrochemical treatment with an array of cylindrical electrodes, we prepared synthetic solutions with concentration of $40 \mathrm{mg} \mathrm{L}^{-1}$ reactive dye Blue $5 \mathrm{G}$ and $2.5 \mathrm{~g} \mathrm{~L}^{-1} \mathrm{NaCl}$. The function of $\mathrm{NaCl}$ is to increase the electrical conductivity in the synthetic effluent, necessary for the electrochemical treatment.

\subsection{Configuration of the sacrificial electrodes}

For the electrochemical treatment using parallel plates, the system studied is composed of an electrolytic chamber, two sources of direct current and three sets of sacrificial iron electrodes separated by approximately $6 \mathrm{~cm}$ and arranged parallel to the flow direction of the synthetic effluent.

As can be observed in Figure 1, the electrode that acts as an anode was positioned equidistant from the other two electrodes (cathodes), in order to allow the two sides of the anode to promote electrolysis. The dimensions of the electrodes, considering the useful area, are: $11 \mathrm{~cm}$ long, $10 \mathrm{~cm}$ wide and $0.6 \mathrm{~mm}$ thick, with a total area of $660 \mathrm{~cm}^{2}$, corresponding to the sum of the areas of the three anodes.

The experimental module used for the electrochemical treatment of synthetic textile effluent using cylindrical electrodes is similar to the experimental module illustrated in Figure 1 , having as basic difference the substitution of the parallel plates by three pairs of cylindrical electrodes, with a useful area of $92 \mathrm{~cm}^{2}$, whose characteristics are shown in Figure 2. 
Figure 1 - Experimental module

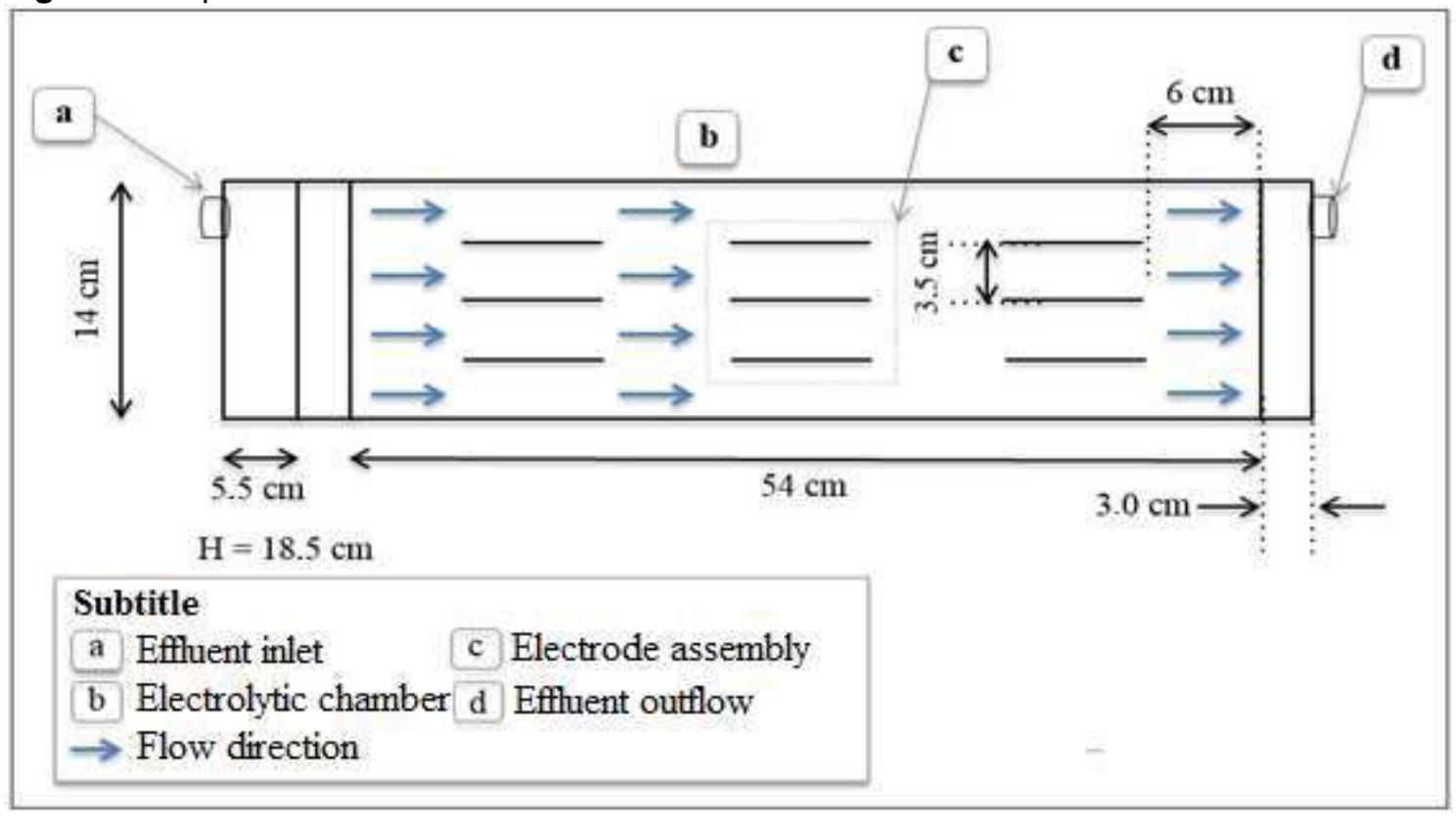

Figure 2 - Characteristics of cylindrical electrodes

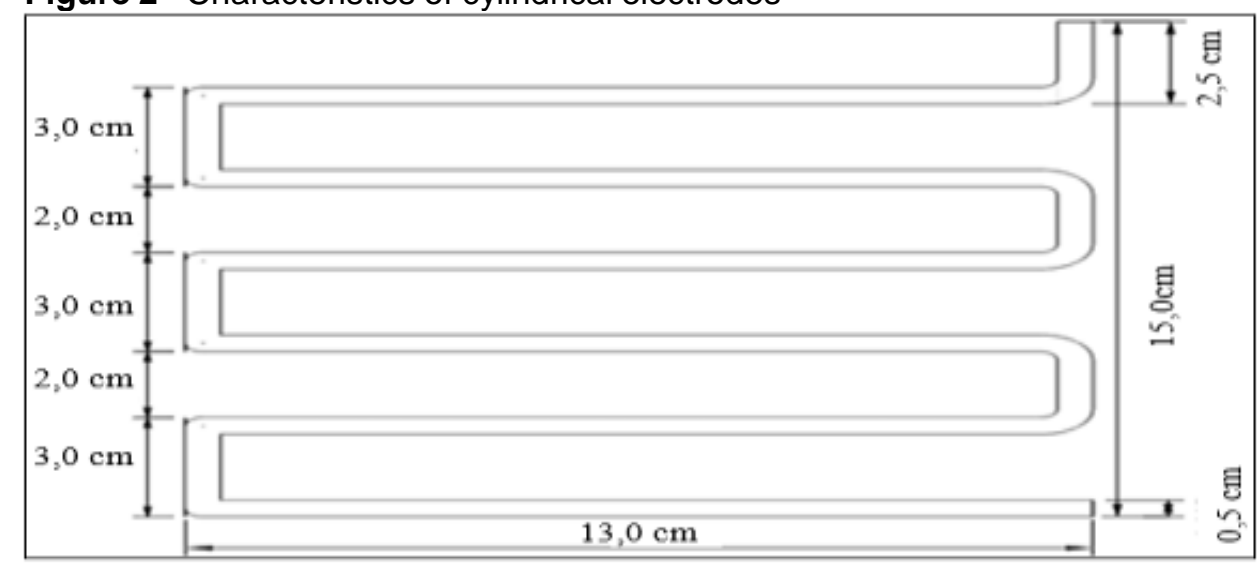

For the production of the cylindrical electrodes, we used CA-50 iron rebar, with ribbed surface and $6.3 \mathrm{~mm}$ diameter. After ready, the electrodes were placed in the electrolytic cell, transversely to the flow of the liquid, with an equidistance of $5 \mathrm{~cm}$.

\subsection{Electrochemical treatment of the synthetic textile effluent}

For the electrochemical treatment using parallel plates, the operating flow rates were adjusted according to each experimental condition by means of a valve installed at the system entry. The negative poles of the power supplies were connected to the electrodes positioned at the center of the set (anode) and the positive poles were connected to the 
external electrodes (cathodes), which are interconnected. In this way, each set consisted of two cathodes and an anode at the center.

Similarly to the electrochemical treatment using parallel plates, for the treatment using cylindrical electrodes, the electric current was obtained through the use of power supplies, three were necessary to meet the electrodes demand.

The synthetic effluent flow rate was adjusted according to the Hydraulic Retention Time (HRT) required for each experimental trial and once the reactor was at its maximum capacity, aliquots were taken in duplicate from the untreated effluent for further analysis of the color.

After adjusting the current density, the time began to be counted according to the specific conditions of each experimental trial. At the end of each HRT, after an additional time necessary for the reactor to be at steady state, aliquots of the electrochemically treated effluent were collected, again in duplicate, for subsequent color removal analysis

Samples were stored in test tubes to be analyzed after decanting for $24 \mathrm{~h}$, a period necessary to decant the residual iron released in the treatment. After the residual iron supernatant was removed, the absorbance was evaluated in a single beam spectrophotometer Hach DR2800 at a wavelength of $618 \mathrm{~nm}$ (SANTOS et al., 2016).

The percentage of color removal, physical-chemical quality parameter of the synthetic effluent, was obtained through Equation 5.

$$
\operatorname{Efficiency}(\%)=\left(\frac{\mathrm{abs}_{\text {in }}-\mathrm{abs}_{\text {out }}}{a \mathrm{abs}_{\text {in }}}\right) * 100
$$

Where:

absin: absorbance of samples collected at the entrance of the electrochemical reactor; absout: absorbance of the samples collected after the electrochemical treatment.

\subsection{Design of treatments}

The Central Composite Rotational Design (CCRD) was the statistical tool used for the experimental design of the present study. Thus, for both configurations of sacrificial electrodes, the influence of the factors of hydraulic retention time (HRT) and electric current density (j), on the color removal efficiency of the synthetic textile effluent, was evaluated 
through a factorial treatment scheme of $2^{2}$, composed of 12 trials.

Table 1 lists the design of treatments with the coded and real values of the factors under study for the electrochemical treatment using parallel plates and with array of cylindrical electrodes, the studied range were defined from preliminary tests.

Table 1- Treatments design matrix

\begin{tabular}{crccc}
\hline Trial & \multicolumn{2}{c}{ Parallel Plates } & \multicolumn{2}{c}{ Cylindrical Electrodes } \\
\cline { 2 - 5 } & HRT (min) & $\mathrm{j}\left(\mathrm{mA} \mathrm{cm}^{-2}\right)$ & $\mathrm{HRT}(\mathrm{min})$ & $\mathrm{j}\left(\mathrm{mA} \mathrm{cm}^{-2}\right)$ \\
\hline 1 & $1(27.00)$ & $1(17.82)$ & $1(22.09)$ & $1(34.14)$ \\
2 & $1(27.00)$ & $-1(6.36)$ & $1(22.09)$ & $-1(14.78)$ \\
3 & $-1(13.00)$ & $1(17.82)$ & $-1(7.91)$ & $1(34.14)$ \\
4 & $-1(13.00)$ & $-1(6.36)$ & $-1(7.91)$ & $-1(14.78)$ \\
5 & $0(20.00)$ & $0(12.09)$ & $0(15.00)$ & $0(24.46)$ \\
6 & $0(20.00)$ & $0(12.09)$ & $0(15.00)$ & $0(24.46)$ \\
7 & $0(20.00)$ & $0(12.09)$ & $0(15.00)$ & $0(24.46)$ \\
8 & $0(20.00)$ & $0(12.09)$ & $0(15.00)$ & $0(24.46)$ \\
9 & $1.41(30.00)$ & $0(12.09)$ & $1.41(25.00)$ & $0(24.46)$ \\
10 & $-1.41(10.00)$ & $0(12.09)$ & $-1.41(5.00)$ & $0(24.46)$ \\
11 & $0(20.00)$ & $1.41(20.18)$ & $0(15.00)$ & $1.41(38.04)$ \\
12 & $0(20.00)$ & $-1.41(4.00)$ & $0(15.00)$ & $-1.41(10.86)$ \\
\hline
\end{tabular}

For each electrode configuration a quadratic mathematical model representative of the process, obtained from the statistical adjustment of the results corresponding to all the trials of the treatment design, was developed using Statistica (version 11.0) (STATSOFT, 2011). The coded mathematical models adjusted from the experimental data, for the electrochemical treatment using parallel plates and array of cylindrical electrodes, are presented in equations 6 and 7, respectively:

$$
\text { Color Removal }(\%)=a_{0}+a_{1} x_{1}+a_{11} x_{1}{ }^{2}+a_{2} x_{2}+a_{22} x_{2}{ }^{2}+a_{12} x_{1} x_{2}
$$

Where:

$\alpha$ : regression model parameters;

$x_{1}$ : coded value of HRT;

x2: coded value of the electric current intensity.

$$
\text { Color Removal }(\%)=\beta_{0}+\beta_{1} \mathrm{y}_{1}+\beta_{11} \mathrm{y}_{1}{ }^{2}+\beta_{2} \mathrm{y}_{2}+\beta_{22} \mathrm{y}_{2}{ }^{2}+\beta_{12} \mathrm{y}_{1} \mathrm{y}_{2}
$$




\section{Where:}

$\beta$ : regression model parameters;

$\mathrm{y}_{1}$ : coded value of HRT;

y2: coded value of the electric current intensity.

The statistical significance of the mathematical models was tested by the Analysis of Variance (ANOVA) with a 95\% confidence interval, and later validated on the basis of color removal efficiency data obtained in a validation test conducted under conditions of HRT and electric current density within the limits at which they were generated, for each configuration of the sacrificial electrodes.

\section{RESULTS AND DISCUSSION}

\subsection{Color Removal Efficiency}

For the electrochemical treatment using parallel plates, as can be seen in Table 2, the color removal efficiency ranged from $56.13 \%$, under the conditions of 12.9 min and 6.36 $\mathrm{mA} \mathrm{cm}{ }^{-2}$ to $98.95 \%$ under conditions of $27 \mathrm{~min}$ and $17.82 \mathrm{~mA} \mathrm{~cm}^{-2}$. For the electrochemical treatment using an array of cylindrical electrodes, the color removal efficiency ranged from $2.11 \%$, under conditions of $7.91 \mathrm{~min}$ and $14.78 \mathrm{~mA} \mathrm{~cm}^{-2}$, to $97.84 \%$, under conditions of $22.09 \mathrm{~min}$ and $34.14 \mathrm{~mA} \mathrm{~cm}^{-2}$. Pinto et al. (2015), using iron electrodes arranged as baffles, obtained $97.62 \%$ color removal of synthetic textile effluent under conditions of $27.1 \mathrm{~min}$ and $10.19 \mathrm{~mA} \mathrm{~cm}^{-2}$, and $5.28 \%$ under conditions $12.9 \mathrm{~min}$ and $3.70 \mathrm{~mA} \mathrm{~cm}^{-2}$.

Aoudj et al. (2010) applied electroflocculation for the removal of color from solutions containing direct dye Red 81 . The effect of hydraulic retention time was studied by adopting a constant electric current density of $2.5 \mathrm{~mA} \mathrm{~cm}^{-2}$. It was noted that increasing HRT from 10 to 60 minutes increased the dye removal efficiency, from $52.5 \%$ to $98.28 \%$. 
Table 2- Color removal efficiency

\begin{tabular}{rccccc}
\hline & Parallel Plates & \multicolumn{3}{c}{ Cylindrical Electrodes } \\
\hline HRT & $\mathrm{j}$ & Color & HRT & $j$ & Color \\
$(\mathrm{min})$ & $\left(\mathrm{mA} \mathrm{cm}^{-2}\right)$ & $\begin{array}{c}\text { Removal } \\
(\%)\end{array}$ & $(\mathrm{min})$ & & \\
& & $\left(\mathrm{mA} \mathrm{cm}^{-2}\right)$ & $\begin{array}{c}\text { Removal } \\
(\%)\end{array}$ \\
\hline $1(27.00)$ & $1(17.82)$ & 98.95 & $1(22.09)$ & $1(34.14)$ & 97.84 \\
$1(27.00)$ & $-1(6.36)$ & 92.71 & $1(22.09)$ & $-1(14.78)$ & 92.46 \\
$-1(13.00)$ & $1(17.82)$ & 94.42 & $-1(7.91)$ & $1(34.14)$ & 88.16 \\
$-1(13.00)$ & $-1(6.36)$ & 56.13 & $-1(7.91)$ & $-1(14.78)$ & 2.11 \\
$0(20.00)$ & $0(12.09)$ & 97.05 & $0(15.00)$ & $0(24.46)$ & 89.80 \\
$0(20.00)$ & $0(12.09)$ & 95.62 & $0(15.00)$ & $0(24.46)$ & 90.82 \\
$0(20.00)$ & $0(12.09)$ & 95.18 & $0(15.00)$ & $0(24.46)$ & 91.15 \\
$0(20.00)$ & $0(12.09)$ & 96.31 & $0(15.00)$ & $0(24.46)$ & 94.66 \\
$1.41(30.00)$ & $0(12.09)$ & 97.63 & $1.41(25.00)$ & $0(24.46)$ & 96.85 \\
$-1.41(10.00)$ & $0(12.09)$ & 72.99 & $-1.41(5.00)$ & $0(24.46)$ & 4.23 \\
$0(20.00)$ & $1.41(20.18)$ & 97.84 & $0(15.00)$ & $1.41(38.04)$ & 97.30 \\
$0(20.00)$ & $-1.41(4.00)$ & 68.21 & $0(15.00)$ & $-1.41(10.86)$ & 34.27 \\
\hline
\end{tabular}

\subsection{Analysis of effects}

Table 3 presents the effects of the factors studied on the response variables. The effect of a factor can be understood as the variation caused in the response variable, when we go through all levels of this factor, independently of the other factors (Rodrigues and lemma, 2009).

The hydraulic retention time and the electric current density and the interaction between these factors had a significant statistical effect on the color removal of the synthetic textile effluent using parallel plates and an array of cylindrical electrodes in the electrochemical process, since the $p$-value obtained is lower than the level of significance adopted, 0.05. The hydraulic retention time and the electric current density (linear terms) for the two configurations of sacrificial electrodes were the only analyzed factors that had a positive effect on the response variable, that is, when the levels of these factors increased, removal of the synthetic effluent also increased. 
Table 3- Effects of the factors analyzed on the color removal

\begin{tabular}{|c|c|c|c|}
\hline \multirow{7}{*}{ Parallel Plates } & Factor & Effect & p_value \\
\hline & Average & 96.04 & $1.12^{*} 10^{-8}$ \\
\hline & $x_{1}(L)$ & 19.02 & $1.00^{*} 10^{-6}$ \\
\hline & $\mathrm{x}_{1}(\mathrm{Q})$ & -10.06 & $1.01 * 10^{-4}$ \\
\hline & $\mathrm{x}_{2}(\mathrm{~L})$ & 21.64 & $1.00^{*} 10^{-6}$ \\
\hline & $\mathrm{x}_{2}(\mathrm{Q})$ & -12.36 & $3.1^{*} 10^{-5}$ \\
\hline & $\left(x_{1}\right) x\left(x_{2}\right)$ & -16.03 & $2.7^{*} 10^{-5}$ \\
\hline \multirow{6}{*}{ Cylindrical Electrodes } & Average & 91.57 & $6.42^{*} 10^{-7}$ \\
\hline & $\mathrm{y}_{1}(\mathrm{~L})$ & 57.83 & $7.17^{*} 10^{-5}$ \\
\hline & $\mathrm{y}_{1}(\mathrm{Q})$ & -35.15 & $1.97^{*} 10^{-3}$ \\
\hline & $\mathrm{y}_{2}(\mathrm{~L})$ & 45.20 & $2.84^{*} 10^{-4}$ \\
\hline & $\mathrm{y}_{2}(\mathrm{Q})$ & -19.81 & $2.58^{*} 10^{-2}$ \\
\hline & $\left(y_{1}\right) x\left(y_{2}\right)$ & -40.33 & $3.13^{*} 10^{-3}$ \\
\hline
\end{tabular}

$\mathrm{x} 1$ and $\mathrm{y} 1$ : coded values of HRT; $\mathrm{x} 2$ and $\mathrm{y} 2$ : coded values of electric current intensity.

\subsection{Mathematical models representative of the process}

The proposed mathematical models representative of the process for the removal of color from the synthetic textile effluent using parallel plates and array of cylindrical electrodes using coded values of HRT and j, are presented in equations 8 and 9, respectively.

Color Removal $(\%)=96.04+9.51 \mathrm{x}_{1}-5.03 \mathrm{x}_{1}{ }^{2}+10.82 \mathrm{x}_{2}-6.18 \mathrm{x}_{2}{ }^{2}-8.01\left(\mathrm{x}_{1}\right) \mathrm{x}\left(\mathrm{x}_{2}\right)$

Color Removal $(\%)=91.57+28.9 \mathrm{y}_{1}-17.58 \mathrm{y}_{1}{ }^{2}+22.60 \mathrm{y}_{2}-9.91 \mathrm{y}_{2}{ }^{2}-20.16\left(\mathrm{y}_{1}\right) \mathrm{x}\left(\mathrm{y}_{2}\right)$

Table 4 lists the results of Analysis of Variance (ANOVA) for statistical validation of mathematical models proposed for color removal for the different configurations of sacrificial electrodes. The quadratic mathematical models representative of the process are statistically significant, since the p-values obtained using parallel plates and array of cylindrical electrodes (8.37E-7 and 1.38E-4, respectively) are lower than the level of significance, 5\%, explaining the total variability of responses in 99.49 and $97.21 \%$, respectively. In this context, it can be inferred that the mathematical models have a good fit to the experimental data. 
Table 4- Statistical validity of the proposed mathematical models

\begin{tabular}{ccccccc}
\hline & $\begin{array}{c}\text { Change } \\
\text { source }\end{array}$ & $\begin{array}{c}\text { Sum of } \\
\text { Squares }\end{array}$ & $\begin{array}{c}\text { Degrees of } \\
\text { freedom }\end{array}$ & $\begin{array}{c}\text { Average } \\
\text { Square }\end{array}$ & p_value & $\mathbf{R}^{2}$ \\
\hline Parallel & Regression & 2314.82 & 5 & 462.96 & $8.37^{*} 10^{-7^{*}}$ & 99.49 \\
Plates & Residues & 11.73 & 6 & 1.96 & & \\
& Total & 2326.55 & 11 & & & \\
Cylindrical & Regression & 15036.78 & 5 & 3007.36 & $1.38^{*} 10^{-4^{*}}$ & 97.21 \\
Electrodes & Residues & 431.17 & 6 & 71.86 & & \\
& Total & 15467.95 & 11 & & & \\
& & & & & &
\end{tabular}

Through the response surface generated by the mathematical models representative of the process (Figure 3), conditions of hydraulic retention time and electric current density can be obtained, which result in greater color removal for the electrochemical process using parallel plates (Figure 3a) and array of cylindrical electrodes (Figure 3b). For the greatest color removal using parallel plates, the optimum range of HRT is between 20 and 30 min and the electric current density is between 12.9 and $20.18 \mathrm{~mA} \mathrm{~cm}^{-2}$. For the greatest color removal using an array of cylindrical electrodes, the optimum range of HRT is between 15 and $25 \mathrm{~min}$ and the electric current density lies between 27.00 and $38.04 \mathrm{~mA} \mathrm{~cm}^{-2}$.

Similarly, in Pinto et al. (2015), there was a wide range with satisfactory results regarding the color removal from synthetic textile effluent. It has been observed that the removal efficiency increases when the operating conditions are greater than 20 min of hydraulic retention time and $6.94 \mathrm{~mA} \mathrm{~cm}^{-2}$ of electrical current density.

\subsection{Validation of proposed mathematical models}

From the optimum ranges of operation of the system in relation to the factors evaluated, the conditions of hydraulic retention time and electric current density applied in the validation of the proposed mathematical models were defined. For the electrochemical treatment using parallel plates and array of cylindrical electrodes, the operating conditions of $20 \mathrm{~min}$ and $15 \mathrm{~mA} \mathrm{~cm}^{-2}$ and $15 \mathrm{~min}$ and $29.02 \mathrm{~mA} \mathrm{~cm}^{-2}$, respectively, were used. Following the recommendations of Rodrigues and lemma (2014), the validation tests of the mathematical models were performed in triplicate, and only the mean values were presented. 
As observed in Table 5, the mathematical models representative of the electrochemical process applied to the color removal from synthetic textile effluent present good predictive ability, with maximum errors of 2.80 and $2.40 \%$ for the system using parallel plates and array of cylindrical electrodes, respectively.

Figure 3(a) - Response surface for parallel plates

Figure 3(b) - Response surface for array of cylindrical electrodes

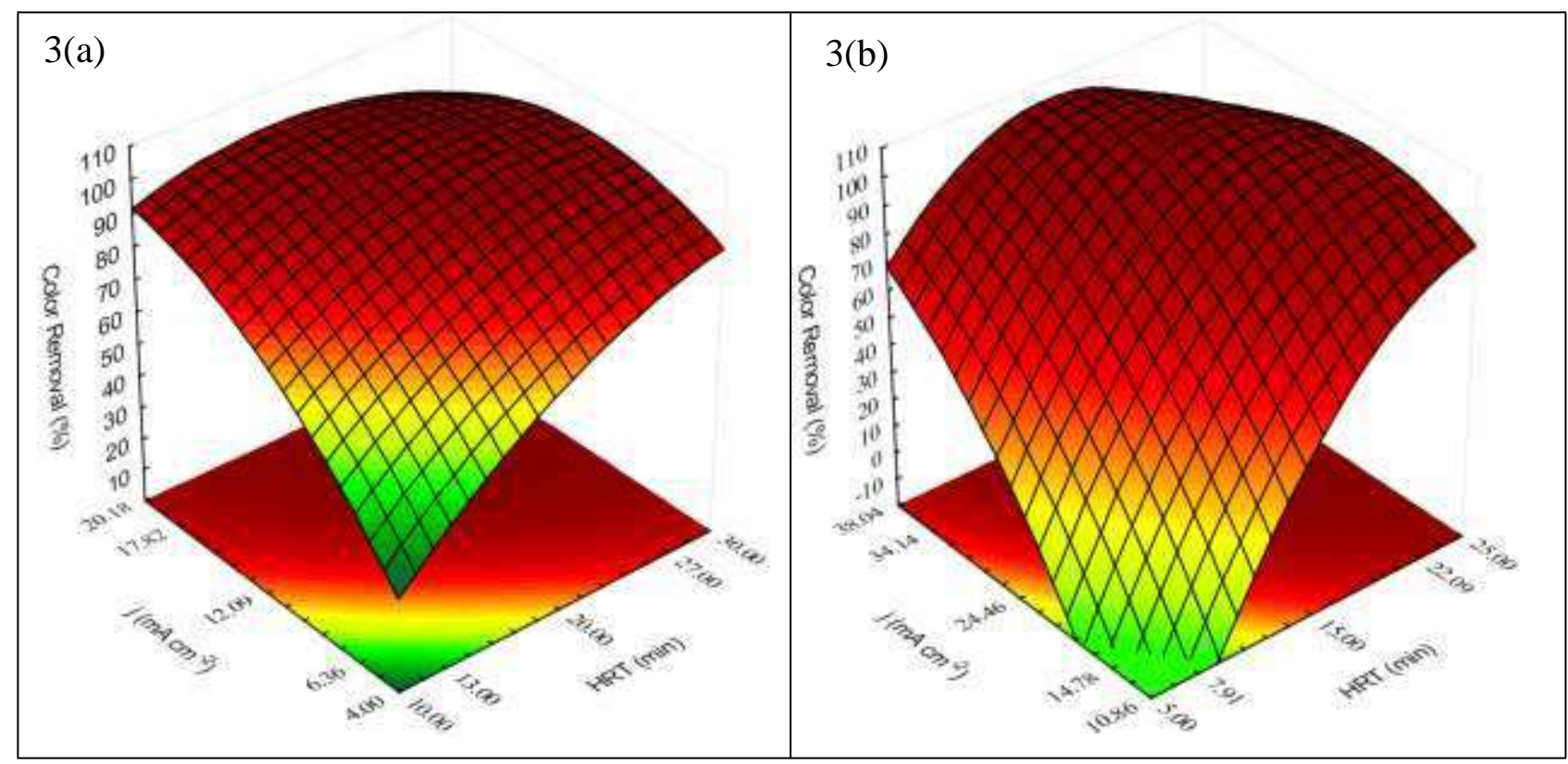

Table 5- Expected and observed color removal for different electrode configurations

\begin{tabular}{cccc}
\hline $\begin{array}{c}\text { Electrodes } \\
\text { Configurations }\end{array}$ & $\begin{array}{c}\text { Expected color } \\
\text { removal (\%) }\end{array}$ & $\begin{array}{c}\text { Observed color } \\
\text { removal (\%) }\end{array}$ & Error (\%) \\
\hline Parallel Plates & 99.90 & $97.18( \pm 0.14)$ & 2.80 \\
Cylindrical Electrodes & 100.00 & $97.66( \pm 0.29)$ & 2.40 \\
\hline
\end{tabular}

\subsection{Comparison between different configurations of sacrificial electrodes}

By simultaneously analyzing the performance of the sacrificial electrodes used in the present study to remove the color of synthetic textile effluent, it is possible to observe similarity in the results obtained, standing out the following:

a) the maximum efficiency of color removal among all conditions of the treatment design was similar for electrochemical treatment using parallel plates and array of cylindrical electrodes, $98.95 \%$ and $97.84 \%$, respectively. 
b) the same factors of the mathematical models representative of the process had a positive effect, hydraulic retention time and electric current density (linear terms), that is, by increasing the levels of these factors it is achieved a greater color removal.

c) the mathematical models representative of the process explain a high proportion of the total data variability, presenting a coefficient of variation of $99.49 \%$ and $97.21 \%$ for parallel plates and array of cylindrical electrodes, respectively.

d) the error associated with the practical application of the mathematical models within the limits in which they were generated is low, $2.80 \%$ and $2.40 \%$ for parallel plates and array of cylindrical electrodes, respectively.

Given the similarities presented, it should be pointed out that the range of electric current density used for the electrochemical treatment with an array of cylindrical electrodes presents higher values than the treatment using parallel plates, which is an indication of higher energy expenditure and, consequently, higher costs.

In order to compare the different configurations of sacrificial electrodes under the same operating conditions, the simulation of color removal efficiency of synthetic textile effluent was performed using the mathematical model representative of the electrochemical treatment with array of cylindrical electrodes when applied optimum conditions obtained with the configuration of parallel plates (20.00 min e $15.00 \mathrm{~mA} \mathrm{~cm}^{-2}$ ). The results show $99.90 \%$ efficiency of color removal using parallel plates and $83.26 \%$ using array of cylindrical electrodes.

Considering the results, it can be inferred that the electrochemical treatment using parallel plates has advantages over the configuration using array of cylindrical electrodes, since, the efficiency of color removal is higher, in $16.64 \%$, under the same operating conditions.

\section{CONCLUSIONS}

The electrochemical treatment proved to be an efficient technique for the removal of color from textile effluent, with satisfactory results under different operating conditions of hydraulic retention time and electric current density.

The electrochemical treatment using parallel plates showed advantages over cylindrical electrodes because the efficiency of color removal is superior under the same operating conditions, which represents economic and environmental gains 
When applying the electrochemical treatment for color removal from textile effluent considering the factors evaluated and the range covered, the simulation of the predicted efficiency can be done with the application of the mathematical models representative of the process, since they were able to satisfactorily describe the color removal data in the validation test performed.

\section{REFERENCES}

AKSU, Z.; TEZER, S. Biosorption of reactive dyes on the green alga Chlorella vulgaris. Process Biochemistry, v. 40, n. 3-4, p. 1347-1361. 2005.

AOUDJ, S.; KHELIFA A.; DROUICHE, N.; HECINI, M.; HAMITOUCHE, H. Electrocoagulation process applied to wastewater containing dyes from textile industry. Chemical Engineering and Processing, v. 49, p. 1176-1182, 2010.

AQUINO NETO, S.; MAGRI, T. C.; SILVA, G. M.; ANDRADE, A. R. Tratamento de Resíduos de Corante por Eletrofloculação: Um Experimento para Cursos de Graduação em Química. Química Nova, v. 34, n.8, p.1468-1471, 2011.

CARNEIRO, P. A.; UMBUZEIRO, G. A.; OLIVEIRA, D. P.; ZANONI M. V. B. Assessment of water contamination caused by a mutagenic textile effluent/dyehouse effluent bearing disperse dyes. Journal of Hazardous Materials. v. 174, p. 694-699, 2010.

CERQUEIRA, A.; RUSSO, C.; MARQUES, M. R. C. Electroflocculation for textile wastewater treatment. Brazilian Journal of Chemical Engineering, v. 26, n. 4, p.659-668, 2009.

CIARDELLI, G.; RANIERI, N. The treatment and reuse of wastewater in the textile industry by means of ozonation and Electroflocculation. Water Research, v. 35, n. 2, p. 567-572, 2001.

DANeShVAR, N.; Oladegaragoze, A.; DJAFARZADEH, N., Decolorization of basic dye solution by electrocoagulation: An investigation of the effect of operational parameters. Journal of Hazardous Materials, n. 129, p. 116-122, 2006.

HASANBEIGI, A.; HASANBEIGI, A.; ABDORRAZAGHI, M. Comparison analysis of energy intensity for five major sub-sectors of the Textile Industry in Iran. Journal of Cleaner Production, v. 23, n.1, p.186-194, 2012.

PASCHOAL, F. M. M.; TREMILIOSI-FILHO, G. Aplicação da tecnologia de eletrofloculação na recuperação do corante índigo blue a partir de efluentes industriais. Química Nova, v. 28, n. 5, p. 766-772, 2005.

PINTO, A. H.; HELMANN, A. C.; EYNG, E.; BARALDI, I. J.; FRARE, L. M. Otimização de reator eletroquímico aplicado ao tratamento de soluções de corante reativo azul 5G. In: CONGRESSO BRASILEIRO DE ENGENHARIA DE PRODUÇÃO, 5., 2015. Anais... Ponta Grossa - PR.

ROBINSON, T; MCMULLAN, G.; MARCHANT, R.; NIGAM, P. Remediation of dyes in textile effluent: a critical review on current treatment technologies with a proposed alternative. Bioresource Technology, v. 77, p. 247-255, 2001. 
RODRIGUES, M. I.; IEMMA, A. F. Planejamento Experimental e otimização de processos. 3. ed. Campinas, SP: Casa do Espírito Amigo Fraternidade Fé e Amor, 2014.

SANTOS, B. S.; EYNG, E.; BITTENCOURT, P. R. S.; FRARE, L. M.; FLORES, E. L.; COSTA, M. B. Electro-flocculation associated with the extract of Moringa oleifera Lam as natural coagulant for the removal of reactive blue 5G dye. Acta Scientiarum. Technology, v. 38, n. 4, p. 483-488, 2016.

StatSoft. Inc. (2011). STATISTICA (data analysis software system). Version 11.0. www.statsoft.com 